\title{
Genetic Analysis in a Melanin-producing Streptomycete, Streptomyces glaucescens
}

\author{
By R. BAUMANN AND R. HÜTTER \\ Microbiology Department, Swiss Federal Institute of Technology, Zürich, Switzerland \\ AND D. A. HOPWOOD \\ John Innes Institute, Norwich NOR $70 \mathrm{~F}$
}

(Received 15 October 1973; revised I November 1973)

SUMMARY

Using crossing and analysis procedures similar to those applied to Streptomyces coelicolor A3(2), several auxotrophic and streptomycin-resistant markers were located on a circular linkage map of the melanin-producing Streptomyces glaucescens, strain ETH22794. The linkage map of $S$. glaucescens is similar to that of $S$. coelicolor $\mathrm{A} 3(2)$, in the sequence of markers and in the presence of two long 'silent' regions.

\section{INTRODUCTION}

Since the first quantitative results of genetic analysis in Streptomyces coelicolor A3(2) (Hopwood, 1959) and the further studies that established a circular linkage map (Hopwood, I965) and a good experimental genetic system (Hopwood, r967; Sermonti, 1969), mapping studies have been extended to other Streptomycetes. The obvious candidates were antibiotic-producing strains. Two of them, Streptomyces rimosus (Alačević, 1969; 1973; Friend \& Hopwood, I97I; Alačević, Strašek-Vešligaj \& Sermonti, I973) and Streptomyces bikiniensis var. zorbonensis (Coats \& Roeser, 197I) were chosen for genetic studies as a possible basis for strain improvement by genetic manipulation. The linkage maps of these two strains were compared with that of $S$. coelicolor A3(2) (Friend \& Hopwood, 197I) and showed a remarkable similarity, as did the linkage map of Streptomyces olivaceus (Matselyukh et al. 1973).

Streptomyces glaucescens strain ETH22794 produces the enzyme tyrosinase and is therefore capable of converting tyrosine to melanin. The tyrosinase of this strain has been purified and characterized by Lerch \& Ettlinger (1972). The studies described in this paper provide a starting point for investigations of the regulation of melanin-production in $S$. glaucescens, as well as yielding further data on comparative streptomycete genetics.

\section{METHODS}

Media. Complete medium (CM), derived from that of Pridham et al. (1956), had the following composition, per litre: Oxoid yeast extract, $4 \mathrm{~g}$; Difco malt extract, $10 \mathrm{~g}$; glucose, $4 \mathrm{~g}$; Oxoid agar, $20 \mathrm{~g}$. The medium was adjusted to $\mathrm{pH} 7 \cdot 3$ with $2 \mathrm{~N}-\mathrm{NaOH}$. This medium was employed for the maintenance of the wild-type and the isolation of auxotrophic and antibiotic-resistant mutants. The glucose-asparagine medium of Waksman (1950) was modified and used as minimal medium (MM). Each litre of MM contained: glucose (auto- 
claved separately as a $50 \%(\mathrm{w} / \mathrm{v})$ solution and added to the medium before cooling), Io $\mathrm{g}$; asparagine, $0.5 \mathrm{~g} ; \mathrm{K}_{2} \mathrm{HPO}_{4}, 0.5 \mathrm{~g} ; \mathrm{MgSO}_{4} .7 \mathrm{H}_{2} \mathrm{O}, 0.5 \mathrm{~g} ; \mathrm{NaCl}, 0.5 \mathrm{~g} ; \mathrm{CaCO}_{3}, 0.2 \mathrm{~g} ;$ Oxoid agar, $20 \mathrm{~g}$. The $\mathrm{pH}$ of the medium was 7.5 and was adjusted if necessary with $\mathrm{KOH}$. This medium was employed with appropriate growth-factor supplementation for crossing, recombinant detection and for the maintenance of mutant strains. Supplements were added to $\mathrm{MM}$ at the following concentrations: amino acids, $100 \mu \mathrm{g} / \mathrm{ml}$; purines and pyrimidines, $20 \mu \mathrm{g} / \mathrm{ml}$; vitamins I $\mu \mathrm{g} / \mathrm{ml}$; streptomycin, $50 \mu \mathrm{g} / \mathrm{ml}$.

Strains. All strains were derived from a single clone of Streptomyces glaucescens strain ETH22794.

Mutagenic treatments and characterization of growth-factor requirements. Mutations were induced by u.v., X-rays and $N$-methyl- $N^{\prime}$-nitro- $N$-nitrosoguanidine (NTG). Glass Petri dishes containing suspensions of $\mathrm{IO}^{9}$ to $\mathrm{IO}^{10}$ spores $/ \mathrm{ml}$ were exposed to a dose of $6 \times 1 \mathrm{IO}^{3}$ to $8 \times 10^{3} \mathrm{erg} \mathrm{m^{-2 }}$ of u.v., or about $160 \mathrm{krad}$ of X-rays. Both procedures were carried out in the dark to prevent photorepair, which is present in Streptomyces glaucescens. Spores were exposed to NTG under the conditions of Delić, Hopwood \& Friend (1970). The intensity of mutagenesis was chosen to give a survival of about I $\%$. Mutants were characterized by the method of Pontecorvo (1952). Antibiotic-resistant mutants were obtained spontaneously by plating spores on $\mathrm{CM}$ or supplemented $\mathrm{MM}$ containing $50 \mu \mathrm{g}$ strepto$\mathrm{mycin} / \mathrm{ml}$.

Genetic markers. The auxotrophic and antibiotic-resistant markers isolated and used during this investigation were designated by standard symbols.

Crossing procedure. The preparations for crossing, the growth of crosses and the isolation and analysis of recombinants were similar to those described by Hopwood (1967) and Friend \& Hopwood (I97I).

All growing cultures were incubated at 28 to $30{ }^{\circ} \mathrm{C}$. The parental strains in a cross differed in at least two markers. Parental cultures, each derived from a purified single clone, were incubated for 3 to 7 days depending on the vigour of sporulation, on supplemented MM either on slants ( $15 \times \mathrm{I} \cdot 5 \mathrm{~cm}$ containing $15 \mathrm{ml}$ ) or in Petri dishes $(20 \mathrm{ml})$ for spore production. Spore suspensions of each parent were prepared by the procedure of Hopwood (1967). The parental spore suspensions were mixed in an approximately $I: I$ ratio (the titre of each parent and the frequency of reversion of the markers were determined in parallel with each cross) and incubated on plates containing a medium allowing both parents to grow. After 4 to 5 days the spores were harvested, diluted and $0.1 \mathrm{ml}$ samples were spread on plates of selective media.

The colonies growing on these selective plates were mostly haploid recombinants, with a variable number of heteroclones and heterokaryons. The recombinant colonies were isolated and analysed by the procedure of Hopwood (1967). If the proportion of heteroclones and/or heterokaryons exceeded $10 \%$ of the random sample of colonies picked from the original selective medium, then the total number of colonies counted on the selective plate was corrected. Complementation tests were carried out by means of the rationale described by Hopwood (1967).

\section{RESULTS}

\section{Preliminary evidence of linkage and map circularity}

The first mapping studies were done using the procedure described by Hopwood (I959). Table I shows the results of such a four-factor cross. Analysis of recombinants on the four different selective media could recover 9 of the possible 16 genotypes, which included at least one member of each complementary pair except the parental pair. The number of 


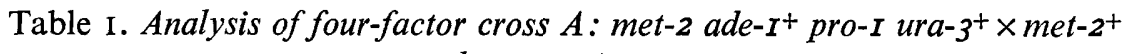
ade-I pro-I $\mathrm{I}^{+}$ura-3

\begin{abstract}
A hundred colonies were isolated from each selective medium and classified into the four possible genotypes to give the numbers in columns $a$; heteroclones and heterokaryons were excluded. Columns $b$ give the frequencies of each genotype/0.I $\mathrm{ml}$ of spore suspension, calculated from columns $a$, and the total selectable progeny/o.I ml of spore suspension. Column $c$ gives the averages of the figures in the four columns $b$.
\end{abstract}

Selective media supplemented with

\begin{tabular}{|c|c|c|c|c|c|c|c|c|c|}
\hline \multirow[t]{2}{*}{$\begin{array}{l}\text { Genotypes of } \\
\text { selectable progeny }\end{array}$} & \multicolumn{2}{|c|}{$\begin{array}{l}\text { Adenine and } \\
\text { methionine }\end{array}$} & \multicolumn{2}{|c|}{$\begin{array}{l}\text { Adenine and } \\
\text { proline }\end{array}$} & \multicolumn{2}{|c|}{$\begin{array}{l}\text { Uracil and } \\
\text { proline }\end{array}$} & \multicolumn{2}{|c|}{$\begin{array}{l}\text { Uracil and } \\
\text { methionine }\end{array}$} & \multirow{2}{*}{$\begin{array}{c}\text { Average } \\
\text { frequency* } \\
c\end{array}$} \\
\hline & $a$ & $b$ & $a$ & $b$ & $a$ & $b$ & $a$ & $b$ & \\
\hline++++ & $3 \mathrm{I}$ & 47 & 32 & 64 & 52 & $7 \mathrm{I}$ & 48 & 77 & 65 \\
\hline$m e t+++$ & 9 & 14 & 一 & - & - & - & II & I8 & 16 \\
\hline+ ade ++ & 46 & 69 & 37 & 74 & - & - & - & - & 72 \\
\hline++ pro + & - & - & 9 & 18 & 9 & I 2 & - & - & 15 \\
\hline+++ ura & - & - & - & - & 39 & 53 & 27 & 43 & 48 \\
\hline met ade ++ & 0 & 0 & - & 一 & 一 & $一$ & - & -1 & 0 \\
\hline++ pro ura & 一 & - & 一 & $\overline{56}$ & 0 & 0 & 一 & -1 & \\
\hline $\begin{array}{c}+ \text { ade pro }+ \\
\text { met }+ \text { ura }\end{array}$ & - & - & $\underline{8}$ & I6 & - & $\overline{-}$ & $\overline{9}$ & $\overline{14}\}$ & 15 \\
\hline Sample size: & 86 & - & 86 & - & 100 & 一 & 95 & - & \\
\hline No. of recombin- & - & 130 & - & 172 & - & 136 & - & 152 & \\
\hline
\end{tabular}

Numbers of recombinants between pairs of markers

$\begin{array}{lcccccc} & \text { met-2-ade-I } & \text { met-2-pro-I } & \text { met-2-ura-3 } & \text { ade-I-pro-I } & \text { ade-I-ura-2 } & \text { pro-I-ura-3 } \\ \text { Components } \dagger & 65 & 16 & 65 & 65 & 72 & 65 \\ & 15 & 15 & 72 & 16 & 48 & 16 \\ & 48 & 0 & 15 & 48 & 0 & 72 \\ \text { Total } & 0 & 15 & 15 & 15 & 15 & 0 \\ & 128 & 46 & 167 & 144 & 135 & 153\end{array}$

* Average frequency of each genotype or pair of complementary genotypes. In the two cases where complementary genotypes can be recovered, their frequencies are not significantly different; therefore the other five figures can each be taken as a measure of the frequency of a pair of complementary genotypes.

$\dagger$ From column $c$. above.

each genotype in the random sample isolated from each medium was then converted to a relative frequency, based on the total count of colonies on that selective medium, which represented a $0 . \mathrm{I} \mathrm{ml}$ sample of the original spore suspension or a dilution of it.

Whereas haploid recombinants yielded vigorously growing replica-patches on the medium identical to the master plate, heteroclones and heterokaryons failed to replicate. The proportions of such colonies analysed on the different media in this cross were not large. During the analysis of recombinants in other crosses we found enormous variation in the numbers of heteroclones and heterokaryons which, as pointed out by Friend \& Hopwood (1971), is to be expected from varying complementation with different combinations of growth factors omitted in the selective medium. Estimates of the numbers of recombinants of a particular genotype recovered on different selective media are in general in good agreement: in Table $\mathrm{I}$, the biggest discrepancy is in the number of the fully prototrophic class, which lies between 47 and 77 . Members of the two pairs of complementary genotypes recoverable also have closely similar frequencies. Thus the numbers in the four columns $b$ 
Table 2. Analysis of marker sequences by means of $2 \times 2$ tables

Each tabulation considers the segregation of the two non-selected markers on one of the four selective media in cross $A$, Table $\mathrm{I}$.

\begin{tabular}{c|cc} 
& met $^{+}$ & $m e t$ \\
\cline { 2 - 3 } ade & $3 \mathrm{I}$ & $9^{*}$ \\
ade & $(\mathrm{I}, 3)$ & $(3,4) \dagger$ \\
& 46 & 0 \\
& $(2,3)$ & $(\mathrm{I}, 2,3,4)$ \\
& \multicolumn{2}{|c}{$P<0.002$}
\end{tabular}

\begin{tabular}{c|cc} 
& pro $^{+}$ & pro \\
\cline { 2 - 3 } ade $^{+}$ & 32 & 9 \\
ade & $(\mathrm{I}, 3)$ & $(\mathrm{I}, 4)$ \\
& 37 & 8 \\
& $(2,3)$ & $(2,4)$ \\
& \multicolumn{2}{|c}{$P=0.27$}
\end{tabular}

\begin{tabular}{|c|c|c|}
\hline & $\mathrm{pro}^{+}$ & pro \\
\hline $\mathrm{ura}^{+}$ & $\begin{array}{c}52 \\
(1,3)\end{array}$ & $\begin{array}{l}9 \\
(\mathrm{I}, 4)\end{array}$ \\
\hline ura & $\begin{array}{c}39 \\
(1,2)\end{array}$ & $\begin{array}{c}0 \\
(\mathrm{I}, 2,3,4) \\
. \mathrm{OI}\end{array}$ \\
\hline
\end{tabular}

\begin{tabular}{c|cc} 
& met $^{+}$ & met \\
\cline { 2 - 3 }$u n$ & 48 & II \\
ura & $(\mathrm{I}, 3)$ & $(3,4)$ \\
& 27 & 9 \\
$(\mathrm{I}, 2)$ & $(2,4)$ \\
& \multicolumn{2}{|c}{$P=0.22$}
\end{tabular}

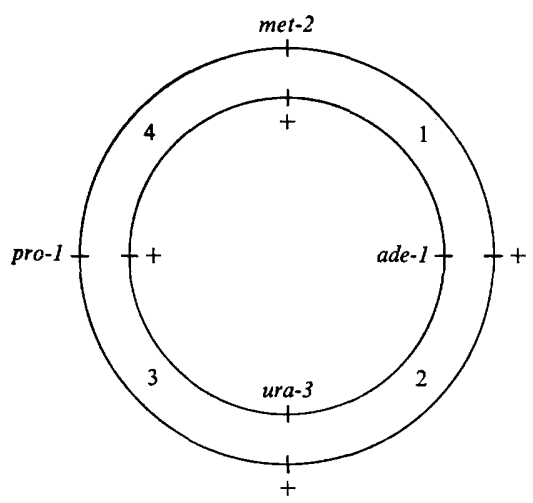

* Frequency of this genotype in the random sample (column $a$ in Table I).

$\dagger$ Crossovers in intervals (indicated in parentheses).

$P$, probability of independence.

can be averaged to give the seven values in column $c$, and these can be taken as measures of the relative frequencies of the seven pairs of complementary recombinant progeny of the cross.

From the seven values in column $c$ of Table $\mathrm{I}$ the relative recombination frequencies between the six pairs of markers can be evaluated. High and almost identical frequencies were found between five pairs of markers (lower section of Table I) and the average of these five values, I47, was set at $50 \%$ recombination. The remaining pair, met-2-pro-I, showed linkage, with a relative recombination frequency of $16 \%[(46 / 147) \times 50]$.

From the data of a four-factor cross analysed as in Table I we can construct $2 \times 2$ tables testing the segregation of the two pairs of non-selected alleles on each selective medium (Table 2). As described by Hopwood (I969), if all four loci in a cross are located on a circular map then the segregation of two adjacent markers is expected to show a lack of independence, whereas two loci separated by a selected marker will show independence. The 
Table 3. Analysis of four-factor cross $B$ : met-2 ade-I pro- $I^{+}$ura- $3^{+} \times$met $-2^{+}$ ade- $I^{+}$pro-I ura- $3^{*}$

Selective media supplemented with

\begin{tabular}{|c|c|c|c|c|c|c|c|c|c|}
\hline \multirow{2}{*}{$\overbrace{}^{\begin{array}{c}\text { Genotypes of } \\
\text { selectable progeny }\end{array}}$} & \multicolumn{2}{|c|}{$\begin{array}{l}\text { Adenine and } \\
\text { uracil }\end{array}$} & \multicolumn{2}{|c|}{$\begin{array}{l}\text { Adenine and } \\
\text { proline }\end{array}$} & \multicolumn{2}{|c|}{$\begin{array}{l}\text { Proline and } \\
\text { methionine }\end{array}$} & \multicolumn{2}{|c|}{$\begin{array}{l}\text { Uracil and } \\
\text { methionine }\end{array}$} & \multirow{2}{*}{$\begin{array}{c}\text { Average } \\
\text { frequency } \ddagger \\
c\end{array}$} \\
\hline & $a$ & $\vec{b}$ & $a$ & $\vec{b}$ & $a$ & $\vec{b}$ & $a$ & $\vec{b}$ & \\
\hline++++ & 14 & 27 & 6 & $2 \mathrm{I}$ & 8 & 26 & 6 & I 2 & 22 \\
\hline met +++ & - & 一 & - & 一 & ro & 33 & 19 & 38 & 36 \\
\hline+ ade ++ & 12 & 23 & 4 & 14 & 一 & - & - & - & 19 \\
\hline++ pro + & - & - & 24 & 82 & 22 & 72 & - & - & 77 \\
\hline$+++u r a$ & 26 & 50 & - & - & 一 & - & $2 \mathrm{I}$ & 42 & 46 \\
\hline+ ade + ura & I & 2 & 一 & - & - & - & 一 & - & \\
\hline met + pro + & 一 & 一 & 一 & - & 0 & 0 & - & - & I \\
\hline+ ade pro + & 一 & 一 & I4 & 48 & - & - & 一 & 一 & 60 \\
\hline met $++u r a$ & 一 & 一 & 一 & 一 & - & - & 44 & 89 & 09 \\
\hline Sample size: & 53 & 一 & 48 & - & 40 & 一 & 90 & - & \\
\hline $\begin{array}{l}\text { No. of recombin- } \\
\text { ants } / 0.1 \mathrm{ml} \text { : }\end{array}$ & 一 & 102 & 一 & 165 & 一 & I 3 I & - & I $8 I$ & \\
\hline $\begin{array}{l}\text { Probability of in- } \\
\text { dependence evalu- } \\
\text { ated from } 2 \times 2 \\
\text { tables: } \dagger\end{array}$ & & & & & & & & & \\
\hline
\end{tabular}

* For explanation, see Table I.

$\dagger$ This tests the independence of the segregation of the two non-selected markers on each selective medium. $\ddagger$ Average frequency of each genotype or pair of complementary genotypes.

Table 4. Analysis of four-factor cross $C$ : ade-I pro-I met-2+ ura- $3^{+}$ $\times$ ade- $I^{+}$pro- $I^{+}$met-2 ura $-3^{*}$

Selective media supplemented with

\begin{tabular}{|c|c|c|c|c|c|c|c|c|c|}
\hline \multirow{2}{*}{$\overbrace{}^{\begin{array}{c}\text { Genotypes of } \\
\text { selectable progeny }\end{array}}$} & \multicolumn{2}{|c|}{$\begin{array}{l}\text { Methionine and } \\
\text { proline }\end{array}$} & \multicolumn{2}{|c|}{$\begin{array}{l}\text { Uracil and } \\
\text { proline }\end{array}$} & \multicolumn{2}{|c|}{$\begin{array}{l}\text { Uracil and } \\
\text { adenine }\end{array}$} & \multicolumn{2}{|c|}{$\begin{array}{l}\text { Methionine and } \\
\text { adenine }\end{array}$} & \multirow{2}{*}{$\begin{array}{c}\text { Average } \\
\text { frequency } \\
\qquad\end{array}$} \\
\hline & $a$ & $b$ & $a$ & $b$ & $a$ & $b$ & $a$ & $b$ & \\
\hline++++ & 0 & 0 & 0 & 0 & $\mathbf{I}$ & 2 & 0 & 0 & 0.5 \\
\hline met +++ & 40 & 60 & 一 & - & 一 & 一 & 34 & 78 & 69 \\
\hline+ ade ++ & - & 一 & 一 & - & 12 & 20 & 2 & 5 & 13 \\
\hline++ pro + & 22 & 33 & 30 & 27 & 一 & 一 & 一 & - & 30 \\
\hline$+++u r a$ & - & - & 9 & 8 & 10 & 17 & 一 & - & I3 \\
\hline met + pro + & 8 & I I & - & - & - & - & 一 & $-\}$ & \\
\hline+ ade + ura & 一 & 一 & - & 一 & 20 & 23 & 一 & $-\}$ & 22 \\
\hline++ pro ura & 一 & 一 & 26 & 24 & 一 & - & 一 & $-\zeta$ & \\
\hline met ade ++ & - & 一 & - & - & - & - & 8 & $19\}$ & 22 \\
\hline Sample size: & 70 & 一 & 65 & 一 & 43 & - & 44 & - & \\
\hline $\begin{array}{l}\text { No. of recombin- } \\
\text { ants/ } \\
0.1 \mathrm{ml} \text { : }\end{array}$ & - & 104 & - & 59 & - & 72 & - & 102 & \\
\hline $\begin{array}{l}\text { Probability of in- } \\
\text { dependence evalu- } \\
\text { ated from } 2 \times 2 \\
\text { tables: } \dagger\end{array}$ & & & & & & & & & \\
\hline
\end{tabular}

* For explanation, see Table I.

$\dagger$ This tests the independence of the segregation of the two non-selected markers on each selective medium.

$\ddagger$ Average frequency of each genotype or pair of complementary genotypes. 

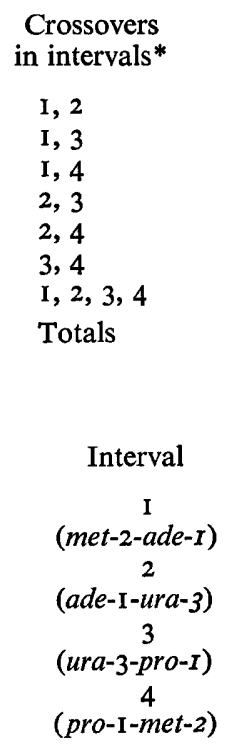

\section{Table 5. Summary of crosses $A, B$ and $C$}

Average frequencies of pairs of complementary genotypes

\begin{tabular}{cccc}
\hline Cross A $\dagger$ & Cross B $\dagger$ & Cross C $\dagger$ & Average (\%) \\
$48(21)$ & $36(13)$ & $30(18)$ & 17 \\
$65(28)$ & $69(26)$ & $22(13)$ & 22 \\
$15(6.5)$ & $19(7)$ & $13(8)$ & 7 \\
$72(31)$ & $77(29)$ & $69(41)$ & 34 \\
$15(6.5)$ & $22(8)$ & $22(13)$ & 9 \\
$16(7)$ & $46(17)$ & $13(8)$ & 11 \\
$0(0)$ & $1(0.4)$ & $0.5(0.3)$ & 0.2 \\
$231(100 \%)$ & $270(100 \%)$ & $169.5(100 \%)$ & $(100 \%)$
\end{tabular}

Total frequencies of crossing-over in each interval

\begin{tabular}{|c|c|c|c|}
\hline Cross A & Cross B & Cross C & Average \\
\hline 55 & 46 & 39 & $46(36 \%)$ \\
\hline 59 & 50 & 72 & $\left.{ }^{60}\right\}_{(50 \%)}$ \\
\hline 66 & 72 & 62 & $\left.{ }_{67}\right\}^{\prime}$ \\
\hline 20 & 32 & 29 & $27(21 \%)$ \\
\hline
\end{tabular}

results in Table 2 follow these predictions exactly when the loci are arranged in a particular sequence.

The final conclusions for this cross are that the loci ade- $I$ and met-2 are close to each other and all four markers are located on a circular linkage map in the sequence shown in Table 2.

A set of three four-factor crosses. By selecting recombinants from a four-factor cross as in Table I, four double auxotrophs can be recovered. Using these recombinants as parents, two further crosses with the same four loci as the original one (cross A, Table I) gave the results shown in Tables 3 and 4 . With such a set of crosses we were able to test the consistency of the conclusions on gene sequence and linkage derived from the first cross. Consideration of the probabilities of independence in Tables 3 and 4 leaves no doubt about the marker sequence.

When the percentage frequencies of the seven pairs of genotypes (that is the seven patterns of crossing-over) in the three crosses are compared (upper section of Table 5), the variation in the estimates is no worse than was found in the estimates of the same genotype on different selective media in each cross. From these data we obtain the total relative frequencies of recombination in the four intervals of each cross, and the average for the three crosses, as shown in the lower section of Table 5. The linkage of met-2-pro-I found in cross $\mathrm{A}$ is present in all three crosses. A linkage between met-2 and ade- $I$ is indicated by the combined data of the three crosses, when the values for the other two intervals are set at $50 \%$, although the distance is too great for linkage to have been recognized confidently from a single cross.

This method of linkage assessment, by means of trios of crosses, has the advantage over heteroclone analysis (Hopwood, Sermonti \& Spada-Sermonti, 1963) that it can be used in 


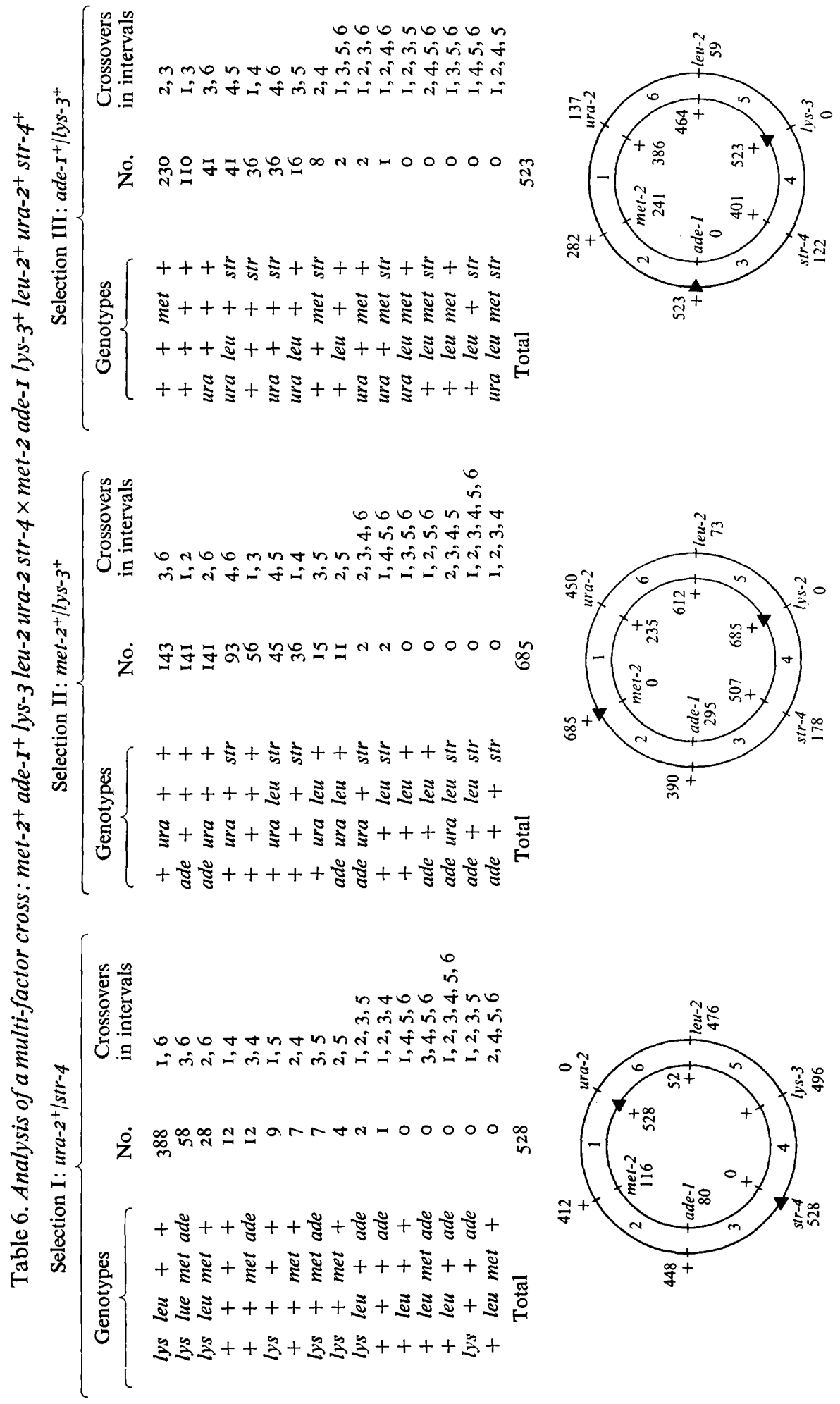


Table 7. Analysis of a seven-factor cross: ade-I+ $\mathrm{I}^{+} \mathrm{ra}-3^{+}$lys-3 leu-2 met-2

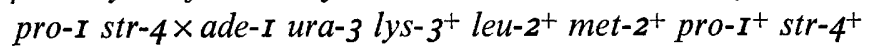

Selection: $s t r-4 / l e u-2^{+}$.

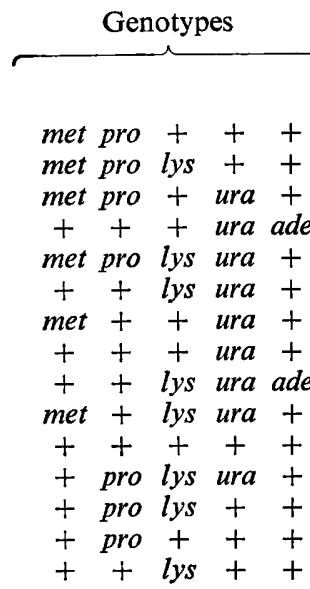

Total:
No.

104

64

46

68

18

20

12

44

8

5

4

I

$\mathbf{I}$

$\mathbf{I}$

397

Hypothesis I

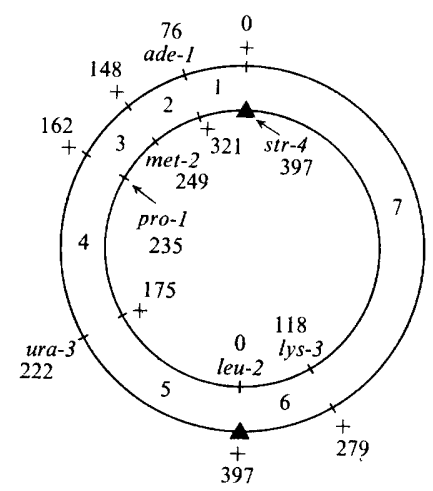

Crossovers required to explain progeny on each hypothesis for the location of ura-3

\begin{tabular}{ll}
\multicolumn{1}{c}{ I } & \multicolumn{1}{c}{ II } \\
5,7 & 4,6 \\
5,6 & 4,5 \\
4,7 & 4,7 \\
I, 7 & I, 7 \\
4,6 & $4,5,6,7$ \\
2,6 & $2,5,6,7$ \\
3,7 & 3,7 \\
2,7 & 2,7 \\
I, 6 & I, 5, 6,7 \\
3,6 & $3,5,6,7$ \\
$2,4,5,7$ & 2,6 \\
$2,3,4,6$ & $2,3,4,5,6,7$ \\
$2,3,5,6$ & $2,3,4,5$ \\
$2,3,5,7$ & $2,3,5,6$ \\
$2,4,5,6$ & 2,5
\end{tabular}

Hypothesis II

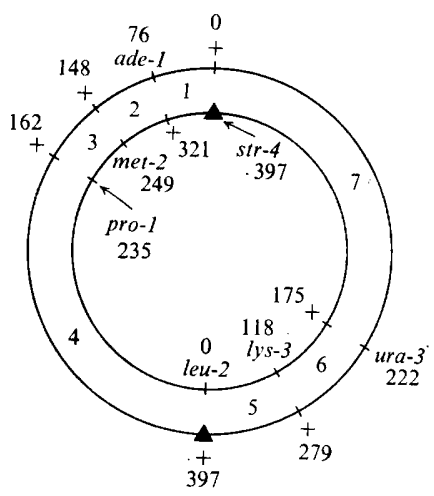

the absence of pairs of closely-linked selectable markers, which are the normal prerequisite for heteroclone selection. It also overcomes the drawbacks of heteroclones in studying linkage over long intervals: few heteroclones are expected to be heterozygous for pairs of distant loci unless selection is made for such rare heteroclones, in which case the segregation of markers within them is likely to be grossly disturbed (Hopwood, I969). It is also a very much less laborious method, particularly since efficient use is made of all the data. The reliability of linkage estimates greater than about $30 \%$ is, of course, likely to be reduced by such factors as zygote incompleteness (Hopwood, 1967) and the possible differential recovery of different genotypes owing to their reduced vigour of growth and/or sporulation.

Multi-factor crosses. The analysis of a multi-factor cross allowing the location of more than one unknown marker is demonstrated in Table 6 . The results of this cross represent three of the possible nine selections between six loci, whose locations on the circular map are unknown. Genotypic analysis of the recombinants from each selection (upper section of 


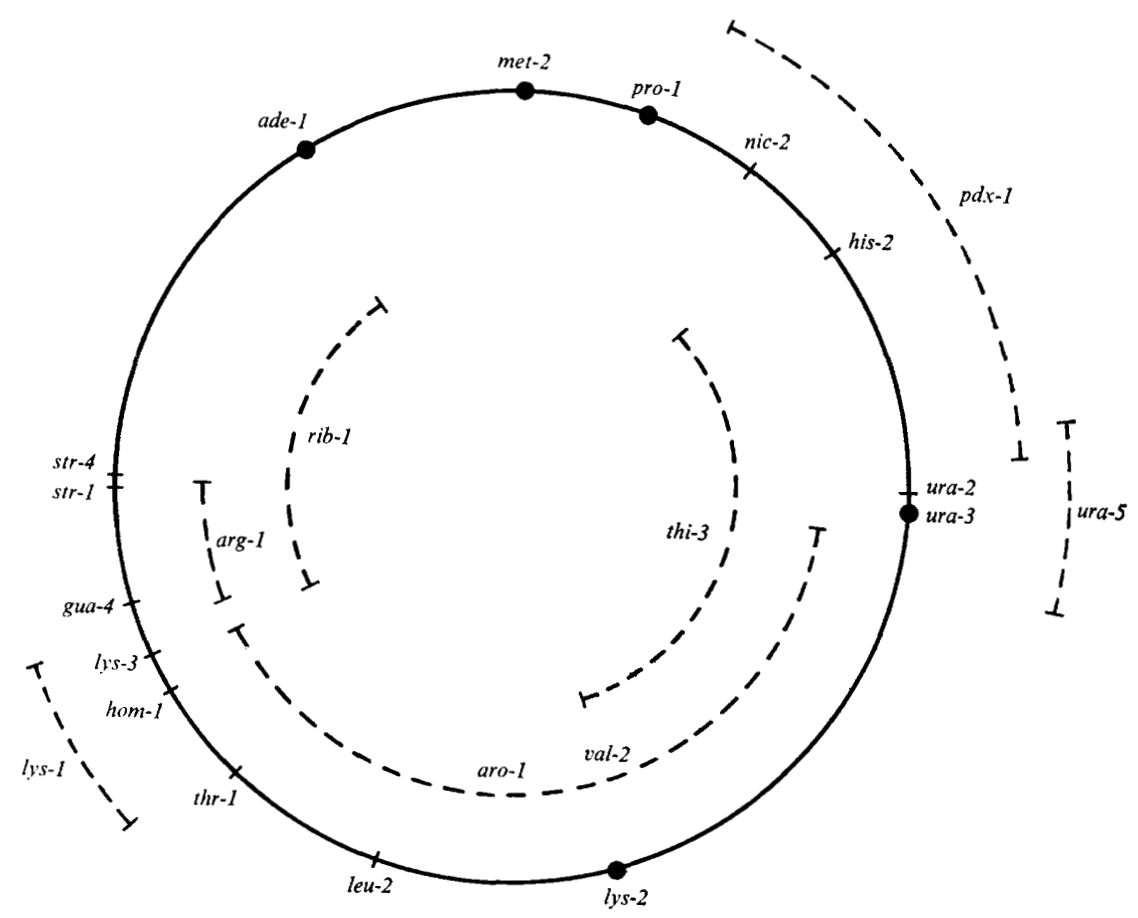

Fig. I. Linkage map of Streptomyces glaucescens strain ETH22794. The five reference loci whose map distances were determined by the analysis of trios of 4 -factor crosses are indicated by the symbol 0 .

Table 6) allows the calculation of the allele ratio at each non-selected locus. These ratios must form an uninterrupted gradient between the selected loci. With $n$ markers there are $2^{(n-3)}$ possible sequencies to consider; in the present example there are eight. The most probable arrangement is that with the lowest number of multiple crossover progeny. In this example (lower section of Table 6) the most probable marker arrangement for each of the three selections is the same.

The kind of analysis in Table 6 reveals the sequence of loci, but not their relative spacings. The same applies to the next example (Table 7) for the efficient mapping, by a single selection, of a new marker ( $u r a-3$ ) in a multi-factor cross with as many as possible of the key loci already mapped. The rationale of such a cross was described by Hopwood (I967). On the basis of its allele frequency, the ura-3 locus could theoretically map between the markers pro- $I$ and leu-2 (hypothesis I, Table 7) or between str-4 and lys-3 (hypothesis II). When the recombinant genotypes are classified in crossover classes, hypothesis II can be ruled out since it would require 54 out of 397 recombinants to be members of multiple crossover classes, whereas on hypothesis I there are only 8 multiples.

The linkage map of Streptomyces glaucescens. Using the mapping procedures discussed above, we obtained the linkage map of Streptomyces glaucescens strain ETH22794 shown in Fig. I. Circularity is implicit in the linkage analysis already described and was further demonstrated by a cross, whose results are not shown, based on the rationale of Hopwood (1965), which was similar to that of Stahl \& Steinberg (I964). Markers indicated by broken arcs have so far not been located exactly. The order of closely linked loci of similar phenotype (ura-2, ura-3, and str-I, str-4) was determined by crosses involving outside markers 


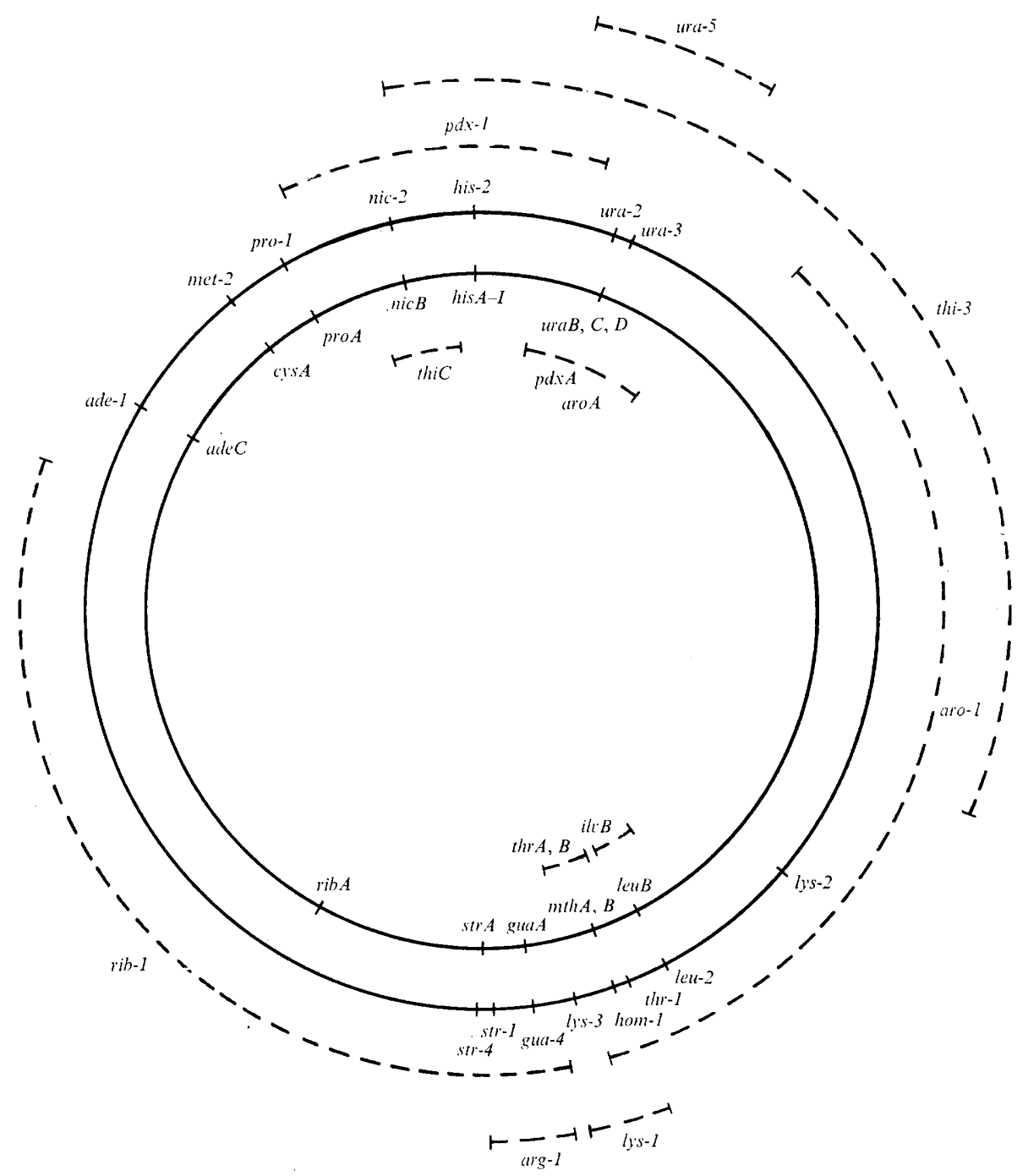

Fig. 2. Comparison of the linkage maps of Streptomyces coelicolor A3(2) (inner circle) and S. glaucescens ETH22794 (outer circle). Only a selection of relevant loci from the linkage map of S. coelicolor (Hopwood et al. 1973) is shown.

(results not shown). The linkage distances of the unambiguously ordered markers on the circular map are based on five reference distances evaluated from the results of several trios of crosses of the type shown in Table 5. Further four-factor crosses, including at least one of the reference distances, then allowed the mapping of new markers.

\section{DISCUSSION}

This study revealed a circular linkage map in Streptomyces glaucescens as in Streptomyces coelicolor A3(2) (Hopwood, 1965), Streptomyces rimosus (Friend \& Hopwood, 1971), Streptomyces bikiniensis (Coats \& Roeser, I97I), and Streptomyces olivaceus (Matselyukh et al. 1973). The methods of linkage analysis based on haploid recombinant selection 
(Hopwood, 1959; 1967; 1969) proved effective in S. glaucescens, and some extensions of the methods were found to be valuable. The occurrence of some heteroclones and heterokaryons together with haploid recombinants on the selective media did not disturb the mapping studies except in rare crosses. The presence of heteroclones was demonstrated by qualitative analysis, but no quantatitive data on them were sought.

The majority of the crosses exhibited an average fertility level of $10^{-4}$ to $10^{-6}$, which is similar to that in IF $\times$ IF crosses in Streptomyces coelicolor A3(2) (Vivian \& Hopwood, I970; Hopwood, Chater, Dowding \& Vivian, I973). Occasionally some crosses gave much higher levels but the significance of such variations in fertility level has not yet been evaluated.

Friend \& Hopwood (197I) described the extreme similarity of the linkage maps of Streptomyces coelicolor and Streptomyces rimosus. It is interesting to see whether this applies also to the map of $S$. glaucescens. In Fig. 2 all the mapped loci of $S$. glaucescens are indicated on the outer circle for comparison with genes of $S$. coelicolor which may be homologous with them. Although several markers in $S$. glaucescens have not been sequenced precisely, there is a much more than random resemblance between the two linkage maps, which is strengthened by the fact that the intervals ura-3-lys-2 and ade-I-str-4 in S. glaucescens are found to be the longest and therefore may correspond to the 'silent regions' in $S$. coelicolor.

The prime reason for extending mapping studies to this strain of Streptomyces glaucescens is its tyrosinase production. Gregory \& Shyu (196I) and Gregory \& Huang (1964) provided strong circumstantial evidence that, in their Streptomyces scabies strains, melanin production is controlled by an extra-chromosomal factor. A reproducible system of recombination analysis in S. scabies has so far proved difficult to establish (Townsend, 1973). The genetic system in $S$. glaucescens, and the known properties of the tyrosinase enzyme (Lerch \& Ettlinger, 1972), now provide an opportunity for a study of the genetic regulation of melanin production.

We wish to thank Professor L. Ettlinger for his interest and encouragement and for his generous financial support (to R.B.) during this work.

\section{REFERENCES}

AlAČEVIĆ, M. (1969). Recombination in'Steptomyces producing tetracyclines. In Symposium on Genetics and Breeding of Streptomyces, Dubrovnik, pp. 137-145. Zagreb: Yugoslav Academy of Sciences and Arts.

AlAČEVIĆ, M. (I973). Genetics of tetracycline-producing streptomycetes. In Genetics of Industrial Microorganisms, Actinomycetes and Fungi, pp. 59-70. Edited by Z. Vaněk, Z. Hoštálek and J. Cudlín. Prague: Academia.

AlaČEviĆ, M., STRAŠEK-VeŠligaJ \& SeRmonti, G. (1973). The circular linkage map of Streptomyces rimosus. Journal of General Microbiology 77, 173-185.

COATS, J. H. \& ROESER, J. (1971). Genetic recombination in Steptomyces bikiniensis var. zorbonensis. Journal of Bacteriology 105, 880-885.

Delić, V., Hopwood, D. A. \& Friend, E. J. (1970). Mutagenesis by $N$-methyl- $N^{\prime}$-nitro- $N$-nitrosoguanidine (NTG) in Streptomyces coelicolor. Mutation Research 9, 167-182.

FRIEND, E. J. \& Hopwood, D. A. (1971). The linkage map of Streptomyces rimosus. Journal of General Microbiology 68, 187-197.

Gregory, K. F. \& Huang, J. C. C. (1964). Tyrosinase inheritance in Streptomyces scabies. II. Induction of tyrosinase deficiency by acridine dyes. Journal of Bacteriology 87, 1287-1 294.

Gregory, K.. F. \& SHYU, W. J. (196I). Apparent cytoplasmic inheritance of tyrosinase competence in Streptomyces scabies. Nature, London I91, 465-467.

Hopwood, D. A. (1959). Linkage and the mechanism of recombination in Streptomyces coelicolor. Annals of the New York Academy of Sciences 8r, 887-898. 
Hopwood, D. A. (1965). A circular linkage map in the actinomycete Streptomyces coelicolor. Journal of Molecular Biology 12, 514-516.

Hopwood, D. A. (1967). Genetic analysis and genome structure in Streptomyces coelicolor. Bacteriological Reviews 3r, 373-403.

Hopwood, D. A. (I969). Genome topology and mapping in Streptomyces coelicolor. In Symposium on Genetics and Breeding of Streptomyces, Dubrovnik, pp. 5-18. Zagreb: Yugoslav Academy of Sciences and Arts.

Hopwood, D. A., Chater, K. F., Dowding, J. E. \& Vivian, A. (1973). Advances in Streptomyces coelicolor genetics. Bacteriological Reviews 37, 37I-405.

Hopwood, D. A., Sermonti, G. \& Spada-Sermonti, I. (I963). Heterozygous clones in Streptomyces coelicolor. Journal of General Microbiology 30, 249-260.

LeRCH, K. \& ETtLINGer, L. (1972). Purification and characterization of a tyrosinase from Streptomyces glaucescens. European Journal of Biochemistry 31, 427-437.

Matselyukh, B. P., Podgorskaya, M. E., Stenko, A. S., Mukvich, N. S. \& Lavrinchuk, V. Y. (I973). Actinomyces olivaceus v KX - a new object for actinomycete genetics. Mikrobiologichni Zhurnal, Kiev 35, 26-36.

PONTECORVO, G. (1953). The genetics of Aspergillus nidulans. Advances in Genetics 5, 15I-238.

Pridham, T. G., Anderson, P., Foley, C., Lindenfelser, L. A., Hesseltine, C. W. \& Benedict, R. G. (1956/57). Antibiotics Annual, 947.

SeRmONTI, G. (1969). Genetics of Antibiotic-producing Microorganisms. London: Wiley-Interscience.

Stahl, F. W. \& SteInBERG, C. M. (1964). The theory of formal phage genetics for circular maps. Genetics 50, $531-538$.

TOWNSEND, M. E. (1973). Genetic studies on Streptomyces scabies. M.Phil. thesis, University of East Anglia, Norwich.

Vivian, A. \& Hopwood, D. A. (1970). Genetic control of fertility in Streptomyces coelicolor A3(2): the IF fertility type. Journal of General Microbiology 64, I0I-1 17.

Waksman, S. A. (1950). The Actinomycetes. Waltham, Massachusetts: Chronica Botanica. 